\title{
Religious Conflict in Terms of Martin Heidegger's Philosophy of Existentialism
}

\author{
Adi Tri Pramono \\ ${ }^{1)}$ Universitas Mulawarman, Jl. Kuaro, Gn. Kelua, Samarinda Ulu, Kabupaten Paser, Kalimantan \\ Timur 75119, Indonesia \\ 1) adi.tri.pramono@feb.unmul.ac.id \\ *corresponding author
}

\section{ARTICLE INFO}

Article history

Received 16 September 2020

Revised 25 September 2020

Accepted 20 October 2020

Keywords

Religious conflict;

Heidegger's Existentialism

Dasein

Education

\section{ABSTRACT}

This paper aims to provide an overview of the process and construction of religious conflict, including genealogy, forms, and analysis of religious conflict causes. Further, this research also provides an indepth analysis of religious conflicts from Martin Heidegger's existentialist philosophy. The methodology employed in this paper is hermeneutics. The research result indicates that the root of religious conflict is fear in facing increasingly modern life. The existence of this fear reduces the presence of the possibility. In the context of Martin Heidegger's existentialist philosophy, the experience is a process of being as Dasein to exist. Therefore religious conflict tends to be taken as a priority decision due to the lack of awareness of existential possibilities. The paper contributes to society in the sense that education must be accessible without any obstacles because, through knowledge, a broader perspective can be obtained since the right to education must be placed prior the right to exist.

This is an open access article under the CC-BY-SA license

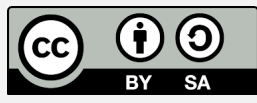

\section{Introduction}

In entering the 3rd millennium, the world was shocked by significant events involving religion. One of the biggest event was the Black September incident i.e. the bombing of the W.T.C. (World Trade Center) building in downtown New York on September 11, 2001. About three thousand human lives were lost, and thousands more were injured. The mass media and many observers in the West alleged that the masterminds and perpetrators behind the incident were the extremist Islamic group, Al Qaida, led by Osama Bin Laden [1].

Almost one year, one month and one day, to be precise, on October 12, 2002, there was another bombing incident at the two discotheques, most visited by foreign tourists; the Sari Club discotheque and Paddy's discotheque in Legian Bali, Indonesia. More than 280 died, and 309 were injured. The Indonesian government indicated that it was caused by religious terrorists who had entered Indonesia [2].

The emergence of religion in the world did not carry an empty meaning. Religions exist to resolve the local community's socio-cultural problems by involving the Supreme Lordship. Pallmeyer reveals that violence leading to religious conflict is more rooted in the tradition of power in sacred religious texts [3]. Pallmeyer also describes that religion has a 
tendency to be a confusing treatise and that religious people cannot blame God for being confused by rhetorical rivalries and unilateral claims [3]. The existence of repressive elements can be traced in history of all religions.

In the genealogy of religious conflict, Christianity has a worse historical story. Crusade, inquisition, and bloody holy wars throughout the 16th to 17 th centuries indicate that Europe has experienced more bloodshed for religious purposes than it has ever done the Islamic world. Some shows that religious people has reduced the text of the religion, hence it is not as comprehensive as it shouls have been. Religions have been clipped according to partial interests, which are considered fundamental for religious people. Thus, as stated by Martin Marty, character assassination on inter-faith religious phenomena happens because of the monoployzed interpretation of the sacred text. This phenomena can be found similar in non-Abrahamic religions tradition. According to Marty [3], Hindu extremists used the Bhagavad Gita as a holy book and used this scripture in their war against the British government. Marty once proposed a question, "Does the religion of the Eastern people love peace?".

This rhetorical question was aimed at Western people who sometimes think of themselves as a more-loving peace beings. Many studies conducted by Marty found that the reduction of religious leaders triggered conflict incidents in this hemisphere. Sri Lanka's Theravada Buddhist priest has long been active in the Sinhalese events and has fought alongside Tamil separatist rebels since 1983. Likewise, the Japanese Buddhists, although they never declared inspired Japanese soldiers to be involved in the "holy war" in World War II.

The primary motivation for religious behavior in embracing religion is how to carry out God's will. According to Søren Kierkegaard (1813-1855), having faith in or relating to God is the peak of self-realization as a spiritual being. In this context, what is essential is not religion as an institution but the individual's practical attitude [4].

The influence of church institutions began to fade, along with the emergence of movements that were very influential in Europe later on. First, the renaissance. This movement marks the rebirth of man in civilization. In this birth, people return to pure sources of knowledge and beauty. In this way, people have the norms that are always applicable to human wisdom and art and they want to rediscover their old cultural heritage against a Greek background. At that time, people began to appreciate the philosophical thought that emphasizes human thinking [5]. Second, Aufklarung (enlightenment). It is a period of refinement from the renaissance period that was initiated in the 18th century. This period is a further development of rationalism, which assumes that the truth is what is accepted by reason. Immanuel Kant (1724-1804), who was considered as the father of enlightenment, emphasizes that enlightenment is a state of escape from immature human thinking. Hence, the right step to correct these mistakes is to "dare to think". Third, the industrial revolution. In this period, human production tools continuously developed to help humans think and work to meet their needs. Together with that, the social view of religion changed drastically and radically. Faith is not only considered less critical for human life, but religion has degenerated solely as a personal matter. This becomes an obstacle to human civilization's progress that relies on science and technology [6].

Another impact of this industrial revolution, apart from being the host of modernization, is a very radical change in the human view of religion as a result of which religion is no longer a determining element in political, social, and cultural thinking. Humans become secular in the sense that they do not base themselves on religion to determine values, but on material needs [7]. Based on the explanation stated, this paper will discuss further, firstly, the process and construction of religious conflict, and secondly, Heidegger's existentialist philosophy in viewing religious disputes. 


\section{Method}

This research employed factual historical literature study by referring to books related to religious conflict and Martin Heidegger's philosophy. The topics were studied using hermeneutic method. Hermeneutics is a method that seeks to explore meaning by considering the horizon that surround the text [8]. The horizon in question includes the horizon of the book, the author, and the reader. Hermeneutics enables understanding or interpreting is an activity of reconstruction and reproduction of the text's meaning of these three horizons. By exploring the (historicity of) author as well as the content the author wants to include in the text, meaning under the situation and conditions when the book is read or understood will be understood. Hermeneutics is also a process of deciphering hidden, moving away from content and purpose that appears. The hermeneutic method is built by using several elements of the technique, such as:

1. Description: this method describes the whole concept of Heidegger's thought and construction in religious conflict coherently.

2. Interpretation: the results of the description will be explored in depth to catch new understandings.

3. Internal Coherence: through systematic understanding, internal structure and hidden correlations in the text so that the research results will be defined explicitly can be found.

\section{Results and Discussions}

\subsection{The Relationship of Heidegger's Philosophy with Previous Philosophy}

According to Reinhold Niebuhr, humans describe a confusing problem and has an existential dimension, both personal and direct [9]. It means that humans have a unique and special place in nature because they have minds that can interpret or reveal meaning in history. Therefore, only humans are historical creatures; humans are the only creatures that are the subject of historical writing capable of making history [9]. On the other hand, human history is impossible if humans are not free. Georg Wilhelm Freidrich Hegel (17701831) revealed that humans are "ein krankes tier" or sick animals. Man always desires to transcend the circumstances he is in; he carries out his possibilities frequently. That is why human existence is still an unfinished subject, but his/her inspiration will always push humans forward. Maurice Merleau-Ponty (1908-1961) also reveals that man is unmouvement de transcendant [9].

Meanwhile, human consciousness, according to Heidegger, is essentially a being-inthe-world ( in-derwelt-sein ), that is a being where it is not only surrounded by objects but being-together-human. Regarding this matter, humans can hold on to Heidegger's thinking that human existence is absolutely a being-with, an existence, an analog of itself [10]. Heidegger becomes a marker for the historical development of Western philosophy after Descartes. Therefore, to understand Heidegger's philosophy, we must first understand the history of Western philosophical thought before, especially ancient Greek philosophy and modern philosophy. By understanding this history, one will get the embryo of the philosophers' ideas who are fundamentally criticized by Heidegger.

The thought before Heidegger's philosophical thinking has a tendencios assumption that the human condition of rationality or as a "thinking object" has consequences on acceptance of the concept that everything that exists in the world is an object. Humans are the only subjects that can grasp the object. This concept comes from Descartes. Furthermore, this subject-object dichotomy is not only limited to the material, but also on 
the idea. In other words, according to Heidegger, this dichotomy led to a concept that everything that is in the world can be consumed because we are humans who can think and be aware of ourselves. As a comparison, an ape does not believe that this world exists (or being) for him because apes lack reflective intelligence. Awareness of being-it-self and being-out-self was at first not be systematized thoroughly until the arrival of Descartes.

For example, ancient Greek philosophy was still in the stage of trying to reduce the whole reality, which was formed by one arkhe (the primary cause). In the period of Socrates (470-399 BC), philosophy has been able to focus on the investigation of humans. Still, it is Plato that presents a systematic way to answer and question problems about previous philosophy. With the theory of ideas, Plato (427-347 BC) explained that all kinds of things in the universe are images of forms in the world of ideas. Forms itself are perfect and eternal ideas. Suppose for a table's state, apart from time and space, a table has every quality that accompanies the human's concept of the table. The eye sees all tables are a lesser imitation of those shown from this form [11].

Furthermore, according to Plato, everything with a form and matter can not only be limited to empirical facts. Abstract ideas also have their conditions, such as justice, conflict, poverty, and so on. However, Plato's concept confronts the problems of time and space. In simple words, how are these forms exist in limited space and time? Plato then conceptualized that humans are more likely to forget these forms after being born into the world. Still, through the use of reason, humans can slowly recall all knowledge about conditions. This process is called anamnesis. Starting from Plato's thought, many great Western philosophy ideas took place until a significant change occurred during Descartes [10].

Descartes' thought became the starting point of the philosophical revolution after Plato. It is also from Descartes' philosophy that the modern era begins. Descartes, the father of modern philosophy, dislikes uncertainty. He wanted a philosophical system as definite and free from doubt as mathematics. For that, he needs "absolute axioms" or universal truths. Descartes then doubts everything; this process is called absolute doubt. Through the inspiration of his dream, Descartes discovered that the axioms are thinking objects. The point is that everything is right if humans thinks about it (cogito ergo sum). This thought becomes the basis of all absolute knowledge and the foundation of the modern philosophical system [11].

This revolution also made philosophers after Descartes more aware of the position of human rationality. The derivation of the very influential Descartes philosophy is about the part of the subject to man. Through rationality, humans can finally assume that something (being), if we think about it, and because of that, it is worthy of "being" an object. In subsequent developments, philosophers found their absolute axioms successively and then made them the basis of their philosophy. An example of this process is the thought of JeanJacques Rousseau (1712-1778). He stated that human beings are harmonious, full of goodness, and these values. According to Rousseau, thses characters are the essence of human nature as oneself. Meanwhile, another example that contradicts diametrically with Rousseau is Francis Bacon (1561-1626) with his empiric axiom.

The contradiction between rationalism and empiricism was "reconciled" by Kant. For Kant, human still cannot reject reality empirically. Yet, at the same time, rationalists are also not wrong to capture empirical perceptions' results uniquely. The process of 'peace' that Kant offered was in the form of presenting categories such as unity, reality, substance, and ability. Kant presupposes that humans have the same means of filtering their 
experiences. Therefore Kant is convinced, like Rousseau, that he can produce universal human knowledge. In Kant's version, these categories of axioms attempt to reconcile philosophers' conflicting axioms but still by creating new axioms. Such a philosophical situation continues. Successively after Kant, the history of western philosophy records Hegel with his historical dialectic and Karl Marx (1818-1883) with his materialism.

Meanwhile, Nietzsche argues that Kant's philosophy has become a very pervasive project in the history of philosophy by continuing to reduce "absolute truth" through its categories. Nietzsche also rejects conventional moral values and requires human beings, as persons, to make their values before others cause them to obey. According to Nietzsche, every organism, life is to increase the life force, and Kant's categories are not absolute truth but a function of the will to power. So the truth, according to Nietzsche, is a question of how human beings can have a 'will to rule' so that through that power, they can interpret what is right. For example, in court cases, the power of the suspect can sometimes influence legal decisions.

Apart from Nietzsche, doubts about absolute truth and the axioms that support it have also been criticized by Soren Kierkegaard. Kierkegaard's most important consideration is the dimension of the timing of philosophers. It means that philosophers or humans only have a limited amount of time; that is, their ages, so it is impossible to know everything if something is limiting them. According to Kierkegaard, a universal truth is unbelievable because truth transcends time, whereas humans are bound to time. That's why humans have to leap. Kierkegaard himself was a Christian, but he did not think that going to church would bring a person closer to God's truth.

Seeing the assumptions to approach this truth came Edmund Husserl with his phenomenology. Husserl emphasized the focus of his research on human action when "experiencing something." For Husserl, human experience is the experience of "about something" so that by investigating it, knowledge can explain things that science cannot solve. For example, someone in love cannot claim to be unhealthy, even if the blood pressure is $140 / 100 \mathrm{mmHg}$. With a concept like this, human experience has been saved from the reduction of science [11].

Furthermore, according to Husserl, by acting as a beginner, one can approach certain phenomena (objects) as they are. So that a person can be free from assumptions outside of himself, as an example of using phenomenology, suppose when someone is investigating about economics. First of all, one must make room for the economy to show its symptoms - Husserl named this process 'brackets' (eingeklammert); this process can sterilize opinion about economics from what has been understood scientifically. It means that economy is diverted as experienced by the perpetrators. The world that is shared by actors in the economy is the object of phenomenology. By Husserl, this kind of world is called the world-life (lebenswelt). This world is everyday life before interpreted by academic scientific approaches. Husserl has the motto zurück zu sachen selbst (get back to things in themselves) to approach the phenomenon as original as possible. So, in the example of economic investigation previously mentioned, economics is not a form of socialism, liberalism, or neo-liberalism but is part of social interaction, a phenomenon concerning the exchange of goods and services. These are economic actors' experiences in everyday life and not rational constructions such as socialism, liberalism, or neoliberalism. However, it does not mean that we can not discuss these reasonable constructions. They are only temporarily suspended, given brackets (eingeklammert), to make room for the 
presence of symptoms carried out by economic actors. Husserl's method gave much inspiration to thinkers, such as Martin Heidegger [10].

Descartes has found the basis for an unshakable philosophy with cogito ergo sum, as explained in the preceding paragraph. Successively after that, various schools of philosophy emerged with their different axioms: rationalism, empiricism, idealism, materialism, and so on. Heidegger does not merely continue the above "isms" but criticizes them fundamentally. His criticism begins with the assumption that Descartes' consciousness is only one way for reality to reveal itself, meaning that awareness of human subjects is not everything, because it tends to have the potential to forget fact [10]. According to Heidegger, everything that exists and has existed the reality is not summarized as in consciousness, matter, or categories.

A coconut can be taken as an analogy. People call coconut not only for its coir, shell, or "coconut", but all of these that make "a coconut" a coconut. It means that by analogy, reality is not something that has been reduced by philosophers. Therefore considering one fact as a whole reality will lead to a deficiency of truth; that is what Heidegger calls forgetting of "being". Reality as a whole is called 'being' (sein), and it is this investigation of being that is at the heart of Heidegger's philosophy of existentialism.

\subsection{Martin Heidegger's Philosophy of Existentialism}

The central thesis that underlies Heidegger's philosophy lies in a master distinction called the ontological difference (ontologische differenz). This distinction is sein and seindes. These terms can be translated into English by "being" (sein) and "beings" (seindes) (10 p.44-5). But what is so interesting about these two terms? Neither do they seem so important to revisit, as if the concept has become something commonly understood? Heidegger criticizes this generality by saying that this generality has made humans forget being (12).

What is being? And what are beings? To help think about the concept of being and beings, let's first understand the idea of being already familiar. The general idea of being is usually just attached in physical objects. For example, a flower was on the table, and then people will tend to interpret being as flowers; it is a position or location in space and time. The concept of being like that, according to Heidegger, is strange, and it is more appropriate to call it beings because the existence of this flower is more dominant as an activity. In truth, activities would not only exist on the table at all times, but may exist in the soil, plants, or flowers that are given to a lover. Therefore, it is more accurate to say flower beings on the table. According to Heidegger, the process of creating something is often reduced to the existence of something so that people tend to focus on being and forget about beings.

Using the flower as example, beings of flowers on the table were more dominant regarded as an entity. Being is a form that envelopes beings (plural form) and enables beings to exist (to happen). But, being is something, not a number or all of beings. However, according to Heidegger, being is more transcendental (12). Therefore, when treating something into an existing condition, it will be found that beings will give the other's possibility of existence or reality. In the context of religion, for example, religion is a being. It means that the existence of faith will allow the beings of religion. In short, when God revealed religion, religion was being by God to guide humans. Through this religion's existence, humans can finally become beings in ways, such as practicing or rejecting religious teachings.

Furthermore, to uncover being forgotten, Heidegger begins by investigating "a being that asks about being" [10]. In this investigation, Heidegger is trying to position a human into being as conscious being. This position is possible because only humans can be aware 
of their being by reflecting on what they have done. This awareness is called reflective consciousness, which characterizes German philosophy, including Heidegger's philosophy. This meditative awareness, according to Heidegger, can be experienced by humans when they question angst (anxiety).

On the one hand, angst is indeed the cause of the forgetfulness of being, because this anxiety often forces people to give in to the consequences of life's routine and not be critical anymore. But on the other hand, through angst, humans can also become aware of and criticize the quality of life they have experienced so far. As an example of the two sides of this angst, for instance, take cellphone ownership. Mobility can be a primary need that must be owned by office workers. This comprises the need to relate to work and family, faster connection and modern lifestyle, which claims cellphones as items that can satisfy humans. In this sense, humans tend to interpret cellphones as tools to fulfil their anxiety about their needs. Still, this quality often stops when that need is satisfied, and then humans are more likely to add more quality and quantity to their needs and try to meet those needs further always.

On the other hand, fulfilling this need will be different if, for example, the office worker uses his cellphone in front of a beggar who asks for alms at a crossroads. If the office worker feels pity and is then followed by reflecting on his condition- in whatever form (not necessarily giving alms)- then, according to Heidegger, the office worker has started to open up questions about being. Heidegger does not ask the man who gave the excess sustenance to impoverish them, or else, to enrich the poor with their expectations, such as how Marx's followers interpret capitalism, but rather invite people to question critically of everything that is being in front of them. Therefore, Heidegger is not talking about a complicated and untouchable concept, but rather things that are so easy for humans to encounter in their daily lives.

Through the problems of human relations with angst as described, Heidegger saw that humans' position was very different. This difference interpreted humans' lives as always ongoing until human death becomes the end of his life. Furthermore, according to Heidegger, a human being is more special because it can question existence [10]. Based on that privilege, Heidegger referred to humans as Dasein. In Sein und Zeit, Heidegger gave humans a new name by calling them Dasein. The term Dasein refers to beings. To understand the meaning between Dasein and humans, Heidegger begins by pointing out the human birth. According to Heidegger, humans are creatures that are 'thrown' (gewonfenheit) when they are born into the world. Humans are never asked whether they want to be accepted or not or shown which direction they will take in this world. This situation is what makes humans just thrown into being. That is what Heidegger's naming Dasein means. Besides, to show Dasein characteristics compared to humans, Heidegger provides an interesting reflection that individual humans' tendency is not happy to be called only humans. For example, Mr. Rusdi, as an individual who lives in society, he is indeed not satisfied if he is generalized as a human being; either will he feel more comfortable if he is respected as his Rusdi; a characteristic of Rusdi who has lived up to that time. In other words, Mr. Rusdi would be happy if his being-in the-world since birth as a differentiator with other human beings. In this way, Heidegger sees humans; humans have valued as beings always and can be aware of their position.

From this understanding, it can be emphasized that it is the position of man as a being who asks to exist. To make it easier to understand this statement, for example, when Mr. Rusdi was sad at one time (beings), he then tried to reopen the life he had been through (being, which consists of beings- plural form). The relationship between the beings with being, is called the question of the being and nothingness, that is, when Dasein beings understood as a process towards being, then being was the one that led to the presence of 
beings. This process continues and lasts until the death of man (Sein zum tode). Heidegger also asserts that Dasein's existence is a constant process of 'becoming' towards the end; therefore, Dasein is a possibility in itself. It means that as a being, Dasein tries to fulfill his existence in the form of options. Dasein positions the word seinkönnen (the possibility itself). With these possibilities, Dasein also has room to determine oneself or decide an option to be determined (done); Heidegger calls this affirmation as jemeinigkeit. The term comes from the word, je meines, which means 'in everything peculiar to mine' $(10, \mathrm{p} .50)$. The meaning of this term is that the possibilities which constitute Dasein's existence, in reality, remain in touch with other Dasein. Therefore, there may be a discourse to find out Dasein's self-attitude.

Thus, according to Heidegger, Dasein has two relationships of beings: the relationship between beings to being called existence, and the relationship between beings to other beings of Dasein which is called to existential (existenziell). Both existence and existential are related to ontological matters because of its nature, which dissolves in life's social interactions [10].

\subsection{Martin Heidegger's Existentialism Correlation of Religious Conflict}

The ontological conflict between religion and science began in the Copernicus (14731543). It was later continued by Galileo (1564-1642), who stated that "the earth revolves around the sun, not the other way around as believed in church teachings (heliocentric)." Religion is the source of much of the moral order in a metaphysical sense when it contradicts Copernicus's claim. This difference of opinion between scientists and church circles marked the beginning of the conflict between science and religion. Galileo, who later became the scapegoat, required to withdraw his statement about the heliocentric. This contradiction occurs in the area of ontology (metaphysics). The adventure to reveal the truth in the phenomenon of the universe should be free of value. While at this stage, the religion's essential about the universe, limiting the ontological contemplation among science to reveal the essence of nature.

It can be said that the real battle is happening between scientists and theologians when it is a religious authority attempts to retain its meaning of reality, while the scientific community is exerting the struggle to free themselves from the values, to reveal the essence of existence. The contradiction in this ontological space was experienced by the church authorities and Copernicus, Galileo, and so on. From this explanation, we can trace that there are similarities between religion and science's metaphysics, namely regarding the disclosure of reality's nature. The persistence of the scientists mentioned above is a determination to find the truth because finding the truth- let alone defending it, requires moral courage.

The history of humanity decorates in the spirit of the martyrs who are willing to sacrifice their lives in defending the truth of what they think is right [13]. Thus, the resistance made by this scientist is ontological in the form of the original truth about the universe. Suppose the church-based its legitimacy from of Bible, while the scientist base it on the principles of the positivistic contemplation. In the $1800 \mathrm{~s}$, scientists eventually gain full autonomy. Autonomy, in a sense, that contemplation activities "ontology" science to uncover the essence of reality is free from the influence of values from outside the ontological area such as religion, ideology, or ethical considerations. It is where science gets the autonomy to develop its studies and research- studying natural phenomena according to the laws that work and regulate natural occurrences, not according to the provisions idealized by religious teachings from the Bible or certain ideologies. Thanks to this autonomy, scientists can expand through ontological processes to give birth to various knowledge. Science then built the basis of epistemological objects that engendered by the 
previous ontological process. Science develops rapidly at this stage because scientists continuously formulate several types of scientific methods of obtaining knowledge. Symptoms of nature and signs of human life (social-humanities) are discovered one by one and continue to add to the treasury of human experience. Similarly, the material object also gave birth to the pure sciences and applied (following the form object), such as economics, biology, law, physics, medicine, physics, agriculture, sociology, anthropology, politics, etc.

The philosophy of science then makes sciences develop themselves with essential ontological and epistemological areas. Meanwhile, applied sciences develop in the crucial axiological area. Positive-empirical science eventually became a pillar of modernism and became the standard of objectivity. Thus, moral and religious values lose their dignity. Consequently, if this pillar does not found in religion, then the material will quickly be considered as an absolute reality [4]. In this kind of context, it is not surprising that the adherents of religious life today, in part, claim that religion has been eliminated from the modern world, or at least only used as a symbol of religiousness.

If traced further, the exclusion of religion from the public world and the emergence of multi-crises in modern society above are the most apparent results of the renaissance and enlightenment (Aufklarung), which began in the 15th century and culminated in the 18th century. These two events had a direct effect on the fertility of the world of science, which later gave birth to the scientific revolution and the industrial revolution [14]. In this case, humans are called not as passive creatures in history. According to Heidegger and Wilhelm Dilthey (1833-1911), this phase to as human history, which is one of the characteristics of human existence. The dimension of historical timeliness becomes a "home" for human behavior, so that according to Bertens, it means that the historical structure of human being is the result of four elements, namely the nature of incarnation, intersubjectivity, and the connection with time and freedom [7]. This intersubjectivity leads to social existence, meaning the presence of humans who are bound in an event is not enough to create true consciousness and freedom. Intersubjectivity occurs when there is a combination of communication and communion of consciousness. It also means that humans cannot interpret as wholly material or pure spirit, and neither is a spirit confined within an earthly body. Humans have to cultivate the material to pour out spiritual possibilities.

According to Armstrong, between the years 1870-1900 is a time about how modern ethos is changing the world. At the end of the 19th century, many Jews, Christians, Islam, and other religions believed that their faith was being hit by hostilities, especially with modernization. Several things force to do to prevent this hostility [14]. First, some of them withdrew completely from modern society and established their militant institutions that functioned as sacred bulwarks and protection. Second, creating a counter-civilization and a discourse against secular modernity. Movements in this second category will later become the mainstream and become the face of the fundamentalist movement. On an individual level, they were able to create massive resistance movements to modernism. Still, on the other hand, they also expressed the belief that there is no conflict between science and religion [15].

Religion, as a religious institution, also produces knowledge power. This institution cannot disclose from the mechanisms and techniques of normative authority. Religion also plays a role in forming identity by uniforming behavior, language, clothing, and rituals. This segmentation of religious identifiers will later help adherents feel ownership of certain social groups to provide social stability, status, outlook on life, ways of thinking, and a particular ethos. This technique of power in religion has brought religion so close to violence [3].

In principle, man is not an object of history, but also a subject. It is not only a product of time circulation but also history. In Western philosophical thought, this concept is called 
historicity and is a characteristic feature of human existence. However, historicity is not always experienced in the same way by humans and the period of civilization. In ancient Greece, understanding human history had not yet emerged because Moira's belief (fate) was so strong that everything that happened is considered absolute. Like the story of Oedipus, who just let his lousy luck befall him. The drama tragedy's audience must accept the drama's conclusion that there is no other way to get this unfortunate fate.

Furthermore, the concept of fate emphasizes in the Stoic school. It concludes that humans would be wise if they let go of their emotions and passions and admit that everything took place with absolute necessity. There is, therefore, no place to fear death. Other perspectives on human historicity differed somewhat during the Middle Ages. The view of historicity, which is fixe on the status of fate, is replaced by the concept of "divine provision" or "God's will" [9].

The awareness about the historicity of the recognition, at the start of the modern age with the project renaissance. In the world of philosophy, Descartes initiated this critical step. Descartes builds the development of ratio autonomy through the cogito ergo sum. Awareness of the independence of reason felt can stop the fatalism, which marked the world view. In the 19th century, the understanding of historicity had seized the intellectual world, many historians and philosophers at the same time were born into significant figures such as Hegel, August Comte (1798-1857), and Marx. From them, historicity thoughts at least have four implications, namely, incarnation, freedom, temporality, and intersubjectivity [9]. In such a critical condition of religion, religious conflict is born, hoping that it will bring certainty to the winners and coolness ( golden age: the heyday of faith). According to Berger, religion has become a "sacred canopy," which means religion is like a holy sky that is shady and protects life and watering the heat of energy to grow plants again. With faith, humans have a sense of peace, dependability, happiness, peace of experience, and protection from situations without meaning [16]. In line with this, Emile Durkheim explained that religion could contribute to the social system, in the sense of a critical point, when humans face uncertainty and helplessness. Religion also offers an antidote for human emotions. Meanwhile, modern life exists as a double-edged phenomenon. It means that on the one hand, the various developments in current institutions provide a wider area of security and comfort of life for humans, but on the other hand, new dangers that are far more deadly come lurking and worrying humans [17].

The concept of how humans treat possibilities and make choices in existence is the focus of Martin Heidegger's thinking. Historicity, which has four elements described above, is constructed as a human process in fulfilling oneself. So, any problems experienced by humans become part of the process of human existence, including human behavior in the history of religious conflicts. Heidegger has never specifically presented thoughts on religious conflict, but that does not mean that the segment on religious conflict has escaped Heidegger's attention. The fundamental ideas of Heidegger can always draw to analyze various phenomena. No matter how complex human ideas and events are, they all reside in historical consciousness with the most superficial understanding.

\subsection{Seeing Religious Conflict As Beings}

The previous paragraph noted that the dimensions of religious conflicts are also greatly influenced by science development. On the other hand, Martin Heidegger's philosophy exists without presenting certainties that claim to be absolute reality. At this level, Heidegger has to be positioned differently from most philosophers. The difference is in modern science criticism, which impacts human thought fabrication, which has excessively reduced. One of them is the metaphysical definition of religion that has existed 
so far. Therefore, as described in the previous chapter, religious conflict construction can be seen as 'simplicity' if people understand Dasein's concept.

At first glance, religious conflict does have a complex dimension, clashes with other life fairies that cannot rule out. Still, once again, for Heidegger, it is not wrong for humans to re-discuss the complexity of religious conflicts as simple things or everyday things. May have been forgotten by humans due to being trapped in angst. First, it must agree that religious conflict is also in existence, among other inventions related to non-religion and religion, such as spirituality in religion. The explanation of this is after humans were 'thrown' by being born into the world, religion can be used as a reference to find out the nature of the 'throwing.' This situation is more likely to position faith in a mythical position.

However, as a person, beings will also be growing linear with their reflection. This reflection will bring possibilities, including criticizing religion's metaphysics, which was initially considered a myth. The case of the existence of these beings is very diverse, but it may tend to be mythical, meaning that the transcendent dimension is more dominant. But once again, Heidegger invites always to return all phenomena to be opened as they are. The critical value in this phase is to avoid reduction. Even though religion cannot answer the question about this existence practically, it must be remembered that humans also have limitations in the form of temporality. The only effort to analyze religious metaphysics is to add perspective to the Dasein-Dasein, who also were beings. This relationship is called existence. In this existence, language is the center, meaning that language is not only used as a means of recognition of identity but is also open, by revealing the existence of a self and the presence of other Daseins.

Understanding Dasein's existence in religion is fundamental because it can assess the extent of knowledge and its possibility when produced by religious actors. And the most mapped chance is that religion is an activity of human surrender to something that is considered very powerful, so there is a value that something will answer later. An example of this statement, the case of the suicide bombings carried out by fundamentalists. The bombings thought carried out are often claimed to be an effort that resolving the conflict, and the bomber does not need legitimacy from many parties because, for him, the bombing is a possibility which he finds very relevant. On the one hand, he is still trapped in temporality so that accepting this kind of world situation becomes very torturous. Yet, on the other hand, he has the ability beyond himself who is aware of his temporality. The same problem is experienced by those who have claimed that religion is nonsense, unscientific. Faith does not found to be a possibility because it is not included in their scientific classification, while to go beyond their limits considers it illogical.

Through Heidegger's phenomenological approach, it can formulate that Dasein's beings in religion would lead to the fulfillment of knowledge being. It means that the form of religion is a process that is continuously fulfilled by beings Dasein. But even so, not all Dasein is automatically able to find beings as the existence of faith. As in the previous paragraph, there is a fabrication of thought from the modern scientific system. The tendency to reduce reality to myth-logos dichotomies, rational-spiritual, brought Dasein stuck not only on temporality alone but also in Dasein's subject position that has understood, both scientific and commonly. According to Heidegger, these dichotomies are only one way to appear, meaning that this does not mean that the contradiction is not valid, but it is not the only one. Being trapped in one of these dichotomies is known as routine; there are angsts that dominate. 


\section{Conclusion}

Issues of how to process and construct understanding of religious conflict, namely the root cause of religious conflict is fear in the face of increasingly modern life. Thus, there is a possibility that it can authentically or specifically take as an attitude before a conflict. In the context of Martin Heidegger's existentialist philosophy, life is no longer interpreted as a process of beings Dasein to exist. In the end, religious conflict movements tend to have complex dimensions; they are innovative, and always modernize themselves. Religious conflict itself occurs due to several reasons, such as:

1. The confusion between rational and mythological discourse. That is when myths/mythical visions become pragmatic policies.

2. It is limited to the literal method of religion for understanding scripture.

3. The distortion of religion for pragmatic political or ideologization interests

4. To maintain holy places, out of longing for the return of "ideal" times.

Besides, from Heidegger's existentialist philosophy of view of religious conflicts, it can be explained that religious conflicts tend to determine prioritized decisions due to the lack of awareness of existential possibilities. Religious conflict is also closely related to modernism. The religious conflict movement exists as a reaction to secular and scientific life. Religious conflicts are even born driven by a sense of fear, anxiety, and general desire, which is a typical response to the difficulties of experience in the modern secular world. In general, religious adherents involved in religious conflicts direct their resistance in two directions at once, namely outward and inward- in the sense of facing the currents of modernism to maintain identity, traditions, and beliefs. It is deeply rooted in the sense of having to compete and be brought face to face with liberal-secular groups in a political and cultural context.

The phenomenon of religious conflict with all its controversies is a "big mirror" for all religious people who still long for "the spirit of religious prophetic". Practically, the real effort to understand and obtain a more objective and wise understanding of this phenomenon is education. Education hence must be accessible without any obstacles because through knowledge, a broader perspective will be obtained. Further, the position of the right to real experience lies after the right to exist. Therefore scientific research, seminars, and discussions should be more geared to this purpose. In this way, religious communities will appreciate that truth is not only a goal but also an existential process.

Acknowledgment: The author thanked Dr. Arqom Kuswanjono, S.S., M.Hum; Dr. Abdul Gafur, S.E., M.Si, Ak., C.A., C.P.A, and Arief Adi Purwoko, S.Fil, M.Hum for their contributions of thought and discussion, thus enabling this research to be revised accordingly.

\section{References}

[1] John L E. Unholy War: Teror Atas Nama Islam. I. Jakarta: Ikon Teralitera; 2013.

[2] Rosiana H. Hari Ini dalam Sejarah: Tragedi Bom Bali I Renggut 202 Nyawa. KompasCom 2019:1. https://www.kompas.com/tren/read/2019/10/12/063000665/hari-ini-dalam-sejarah-tragedi-bom-bali-i-renggut-202-nyawa?page=all (accessed September 9, 2020).

[3] Pallmeyer JN. Is Religion Killing Us?: Violence in the Bible and the Quran. 1st ed. New York: 2003. p.xi

[4] Sugiharto BI, Rachmat AW. Wajah Baru Etika dan Agama. 4th ed. Yogyakarta: Kanisius; 2000. p.100 
[5] Hadiwiyono H. Sari Sejarah Filsafat Barat 2. 24th ed. Yogyakarta: 1990. p.85

[6] Karyono R. Fundamentalisme dalam Kristen-Islam. Yogyakarta: Kalika; 2003. p.25

[7] Soetapa D. Asal-Usul Gerakan Fundamentalisme. Ulumul Qur'an 1993;IV.

[8] Mochtar L. Hermeneutika: Pemahaman Konseptual dan Metodologis. J Unair 2009:3.

https://www.google.com/url?sa=t\&rct=j\&q=\&esrc=s\&source=web\&cd=\&cad=rja\& uact $=8 \&$ ved=2ahUKEwi9muewhuLrAhVFcCsKHTY8D3UQFjAHegQIChAB\&url $=$ http $\% 3 \mathrm{~A} \% 2 \mathrm{~F} \% 2 \mathrm{Fwww}$.journal.unair.ac.id $\% 2 \mathrm{FfilerPDF} \% 2 \mathrm{FHermeneutika.pdf \& us}$ g=AOvVaw0GwAdK_ 9h3Siq9hgQTBd4 (accessed September 9, 2020).

[9] Basarah D. Konsep Historisitas dalam Eksistensi Manusia Menurut Martin Heidegger (1889-1976). University of Gadjah Mada, 1997. p.15

[10] Hardiman FB. Heidegger dan Mistik Keseharian. 1st ed. Jakarta: KPG; 2003. p.15-6

[11] Lemay E. Heidegger untuk Pemula. Yogyakarta: Kanisius; 2001. p.16

[12] Heidegger M. Being and Time. Oxford: Blackwell; 1962. p.22

[13] Suriasumantri JS. Filsafat Ilmu: Sebuah Pengantar Populer. 20th ed. Jakarta: Pustaka Sinar Harapan; 2007. p.25

[14) Capra F. Titik Balik Peradaban. 5th ed. Yogyakarta: Bentang Budaya; 2002. p.52-5

(15] Armstrong K. Berperang demi Tuhan: fundamentalisme dalam Islam, Kristen dan Yahudi. Jakarta \& Bandung: Serambi dan Mizan; 2013. p.225-6

[16] Nashir H. Agama \& Krisis Kemanusiaan Modern. Yogyakarta: Pustaka Pelajar; 1997. p.41

[17] Juliawan BH. Dunia yang Berlari. 49 2000:45. 